\section{PENELITIAN PENGARUH NAPHTHENIC OIL DAN CARBON BLACK TERHADAP SIFAT KEKERASAN LIS KACA MOBIL}

\author{
Oleh : Any Setyaningsih, Siti Rohani
}

\section{ABSTRACT}

This research have a purpose to know influence naphthenic oil and carbon black about properties hardness weather strip for auto mobile. Compound weather strip for auto mobile propert Natural Rubber (RSS) and sintetic rubber (SBR 1502) with in creasing ingrediens make for Natural Rubber (RSS) and sintetic rubber (SBR formula making variation naphthenic oil 3,5 and 7 part along with carbon black 45, 50 and 55 part result hardness test with value 67 shore A for compount with naphthenic oil 7 part and carbon black 50 part and after perform make in to fill requrements SNI 1490-89 A weather strip auto mobile.

\section{INTISARI}

Penelitian ini bertujuan untuk mengetahui pengaruh naphthenic oil dan carbon black

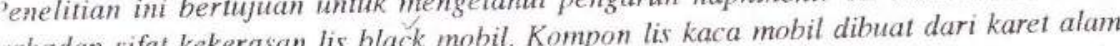
terhadap sifat kekerasan lis hlack mobil. Kompon lis kaca mobil dibuat dari karet alam (RSS) dan karet sintetik (SBR 1502) dengan ditambahkan bahan-bahan pembantu (ingredient) seperti bahan pelunak, pengaktif pengisi, anti oksidan, pencepat dan zat pemvulkanisasi formula kompon dibuat dengan memvariasikan naphthenic oil 3,5 dan 7 bagian serta car formula kompon dack 45,50 dan 55 bagian diperoleh hasil uji kekerasan dengan nilai 67 shore A dar bon black 45,50 dan 55 bagian diperoleh hasil uji kekerasan dengan dan setelah dilakukan kompon dengan naphthenic oil 7 bagian dan carbon black 50 bagian dan setetah dilakukan pembuatan di industri menengah : tau batas dan industri kecil, hasilnya uji kekerasannya pembuatan di indus

memenuhi persyaratan SNI-1490-89A. Lis karel kacakent

\section{PENDAHULUAN}

Lis kaca kendaraan bermotor roda empat adalah salah salu komponen kendaraan bermotor yang banyak dibuat dari bahan karet. Lis kaca kendaraan bermotor tersebut dapat dibuat dengan proses ekstrusi sehingga disini harus diketahu kekerasan yang sesuai dan memenuhi persyaratan untuk dapat diproses.

lis karet kendaraan bermotor dihasilkan dengan cara ekstruksi. Ekstruks adalah proses pencetakan barang yang dikeluarkan melalui lubang atau die dar mesin yang dilengkapi dengan alur pendorong. Mesin yang digunakan untuk proses ekstruksi disebut ekstruder dimana barang yang dihasilkan divulkanisasi secara kontimue. Untuk mendayatkan kecepatan ekstruksi yang tinggi dan hasil akhir yang baik apabila digunakan filler dengan mutu yang tinggi seperti carbon black dan penguat China Clay maka pelunaknya lebih baik digunakan napthenic oil atan otomatic oil. Kekerasan dapat dipertahankan agar tidak berubah selama ckstruksi dan vulkanisasi dengan menggunakan accelerator (3) Filler yang digunakan dalam proses pembuatan lis kaca kendaraan bermotor in adalah carbon black. Carbon black adalah koloida yang dibuat dari dekomposisi panas dari hidrokarbon, gas atau cairan oleh penocrasan atau proses pemhakaran. Ada beberapa proses pembuatau carbon black yastt proses (hanel, Fumace, I amp Black, Thermal dan Acetyleuc. Dari macam-macam proses tersebut masih terdapat macam macam Produknya yaitu untuk proses furnace misalnya menghasilkan : SRI, (iPI IIAI dan sehagainya.

Dalan penelitian ini digunakan (arbon Black jenis $1 \mathrm{~A}$ ' dimana $\mathrm{H}$ Al mempunyan luas permukaan yang sama dengan MPC. Luas permukatan dari koloida dengan struktur carbon bisa menambah kekerasan dan tegangan (2)

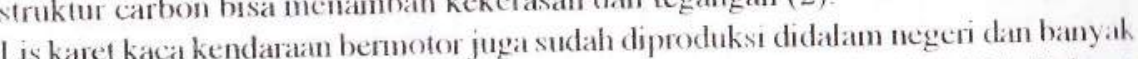
lis karet kaca kendarata beris beredar dipasaran, tetapi padat kaca kendaraan bermotor untuk kekerasannya. () eh karlla itu pertu dilaknkan penclitian pengaruh Naphol

kaca kendaraan bermotor

\section{MAIIRI DAN METOIOA PI NIIIIIAN}

1. Matcri

Baha baku, bahan pembantu dan peralatan yang digunakan dalam penelitian adalah sebagai berikut

Bahan baku

Karet alam : Rubber smoked sheet (RSS I)

Karet sintetis: Styrene Butadiene Rubber (SBR 1502)

Bahan pembantu

Bahan pelunak : naphthenic oil, paraffin wax

Bahan pengaktif: $\mathrm{ZnO}$, asam stearat

- Bahan pencepat : Santocure CBS, TMTD

Bahan pengisi : HAF black, $\mathrm{Ca} \mathrm{CO}_{3}$

- Anti Oksidan : AOSP

- Zat pemvulkanisasi : Sulphur

- Memperbaiki kenampakan : Factice oil

\section{Peralatan}

Pembuatan kompon : timbangan, pisau potong, krus porselin, two roll mill, sla pencetak kompon, hydroulik press, stop watch.

Peralatan pembuatan barang jadi : Extruder, nampan (loyang), almari vulkanisa Alat uji : alat uji kekerasan (Dorumeter Shore A0.
Majalah Barang Kulit, Karet dan Plast 
1. Metode Penelitian

Formula penelitian adalah scbagai berikut

Bahan

RSS I

SBR 1502

Bagian beral

Asam Stearat

Factice ()il

$\mathrm{ZnO}$

Paraffin wax

Naphthenic Oil

$\mathrm{CaCO}$,

HAF Black

Santocure CBS

AOSP

TMTD

Sulphur

\section{HASIL PENELITIAN DAN PEMBAHASAN}

Tabel 1. Data uj kekerasan kompon hasil penclitian dan uji kekerasan lis kaca mobil dari pasaran dan uji kekerasan hasil prototype barang jadi

\begin{tabular}{|c|c|c|c|c|c|c|c|c|}
\hline \multirow[b]{2}{*}{ No } & \multirow[b]{2}{*}{ P'engujian } & \multirow[b]{2}{*}{ Satuan } & \multicolumn{2}{|c|}{$\begin{array}{c}\text { Ilasil } \\
\text { Penelitian }\end{array}$} & \multicolumn{2}{|c|}{ Pasaran } & \multirow{2}{*}{$\begin{array}{c}\text { Masit } \\
\text { prototype } \\
\text { barang jadi }\end{array}$} & \multirow{2}{*}{$\begin{array}{c}\text { Persyaratia } \\
\begin{array}{c}\text { SNI } 1490 \\
89 \mathrm{~A}\end{array}\end{array}$} \\
\hline & & & Kode & Nilai & Kode & Nilai & & \\
\hline & Kekerasan & shore $A$ & Al & 70 & KP II & 60 & \multirow[t]{9}{*}{60 dan 70} & \multirow[t]{9}{*}{$70 \pm 5$} \\
\hline & & & $\triangle 2$ & 71 & $\mathrm{PII}$ & 53 & & \\
\hline & & & A. 3 & 72 & TA I & 62 & & \\
\hline & & & $\mathrm{BI}$ & 69) & TA 11 & 54 & & \\
\hline & & & B2 & 68 & & & & \\
\hline & & & B3 & 71 & & & & \\
\hline & & & $\mathrm{Cl}$ & 68 & & & & \\
\hline & & & $\mathrm{C} 2$ & 67 & & & & \\
\hline & & & $\mathrm{C} 3$ & 73 & & & & \\
\hline
\end{tabular}

Tabel 2. : Analisa Sidik Ragam (ANOVA) untuk kekerasan

\begin{tabular}{|l|c|c|c|c|c|c|}
\hline \multirow{2}{*}{ Sumber variasi } & \multirow{2}{*}{$\mathrm{dk}$} & & \multirow{2}{*}{$\mathrm{J}$} & \multirow{2}{*}{ RJK } & \multirow{2}{*}{ F hitung } & \multicolumn{2}{|c|}{ F label } \\
\cline { 6 - 8 } & & & & & $5 \%$ & $1 \%$ \\
\hline Ulangan & 2 & 20,744 & 10,372 & & & \\
\hline Perlakuan & 8 & $1,092,633$ & - & & & \\
\hline Naphthenic oil & 2 & 12,74 & 6,37 & $22,1951^{* *}$ & 3,63 & 6,23 \\
\hline Carbon Black & 2 & 720,744 & 360,372 & $125,5651^{*}$ & 3,63 & 6,23 \\
\hline $\begin{array}{l}\text { Inretaksi Naphthe } \\
\text { nic Oil X Carbon } \\
\text { Black }\end{array}$ & 4 & 18,1489 & 45,372 & $15,8090^{* *}$ & 3,01 & 4,77 \\
\hline Kekeliruan & 16 & 45,923 & 0,2870 & & & \\
\hline Total & 26 & 109,63 & & & & \\
\hline
\end{tabular}

* Sangat berbeda nyata

** Berbeda nyata 
1. Metode Penelitian

Formula penelitian adalah sebagai beriku

Bahan

RSS I

SBR 1502

Asam Slearal

Factice (Bil

$\mathrm{ZnO}$

Paraffin wax

Naphthenic Oil

$\mathrm{CaCO}$

HAF Black

Santocure CBS

AOSP

TMTD

Sulphur

\section{HASIL PENELITIAN DAN PEMBAHASAN}

Tabel 1. Data uji kekerasan kompon hasil penelitian dan uji kcherasan lis kaca mobil dari pasaran dan uji kekerasan hasil prototype barang jadi

\begin{tabular}{|c|c|c|c|c|c|c|c|c|}
\hline \multirow[b]{2}{*}{ No } & \multirow[b]{2}{*}{ P'cngujian } & \multirow[b]{2}{*}{ Satuan } & \multicolumn{2}{|c|}{$\begin{array}{c}\text { Masil } \\
\text { Penelitian } \\
\end{array}$} & \multicolumn{2}{|c|}{ Pasaran } & \multirow{2}{*}{$\begin{array}{l}\text { Masil } \\
\text { prototype } \\
\text { batang jadi }\end{array}$} & \multirow{2}{*}{$\begin{array}{c}\text { Persyaratiu } \\
\text { SNI } 1490 \\
89 \mathrm{~A}\end{array}$} \\
\hline & & & Kode & Nilat & Kode & Nilai & & \\
\hline & Kekerasan & shore A & $\mathrm{Al}$ & 70 & KP II & 60 & \multirow[t]{9}{*}{$6(1)$ dan 70} & \multirow[t]{9}{*}{$70 \pm 5$} \\
\hline & & & $\mathrm{A} 2$ & 71 & P II & 53 & & \\
\hline & & & $\mathrm{A} 3$ & 72 & TA I & 62 & & \\
\hline & & & $\mathrm{BI}$ & 69 & TA 11 & 54 & & \\
\hline & & & B2 & 68 & & & & \\
\hline & & & B3 & 71 & & & & \\
\hline & & & $\mathrm{Cl}$ & 68 & & & & \\
\hline & & & $\mathrm{C} 2$ & 67 & & & & \\
\hline & & & $\mathrm{C} 3$ & 73 & & & & \\
\hline
\end{tabular}

Tahel 2.: Analisa Sidik Ragam (ANOVA) untuk kekerasan

\begin{tabular}{|l|c|c|c|c|c|c|}
\hline \multirow{2}{*}{ Sumber variasi } & \multirow{2}{*}{$\mathrm{dk}$} & Jk & \multirow{2}{*}{ RJK } & \multirow{2}{*}{ Fhitung } & \multicolumn{2}{|c|}{ F tabel } \\
\cline { 6 - 8 } & & & & & $5 \%$ & $1 \%$ \\
\hline Ulangan & 2 & 20,744 & 10,372 & & & \\
\hline Perlakuan & 8 & $1,092,633$ & - & & & \\
\hline Naphthenic oil & 2 & 12,74 & 6,37 & $22,1951^{* *}$ & 3,63 & 6,23 \\
\hline Carbon Black & 2 & 720,744 & 360,372 & $125,5651^{*}$ & 3,63 & 6,23 \\
\hline $\begin{array}{l}\text { Inretaksi Naphthe } \\
\text { nic Oil X Carbon } \\
\text { Black }\end{array}$ & 4 & 18,1489 & 45,372 & $15,8090 * *$ & 3,01 & 4,77 \\
\hline Kekeliruan & 16 & 45,923 & 0,2870 & & & \\
\hline Total & 26 & 109,63 & & & & \\
\hline
\end{tabular}

* Sangat berbeda nyata

*** Berbeda nyata
Analisa data

Data-data hasil pengujian dianalisa secara statistik dengan menggunakan metoda faktorial

Bes Pembuatan Kompon Lis Kaca

Karet alam dianastikasi dalam two roll mill kemudian ditambah SBR 1502, di giling sampai plastis dan suhu two roll mill dijaga sampai dengan suhu $70^{\circ} \mathrm{C}$ Kemudian ditambahkan secara berurutan paraffin wax, factice oil, $\mathrm{CaCO}_{4}, \mathrm{Na}$ phthenic oil dan HAF black digiling sampai homogen

en ditambahkan Zn O asam stearat, AOSP, Santocure CBS, TMTD se cara berurutan digiling sampai homogen, terakhir ditambah sulphur.

Kompon disimpan dalam ruang kondisioning selama \pm 24 jam.

Kemudian dilakukan uji cure time untuk mengetahui waktu optimum kemasakan kompon pada suhu $150^{\circ} \mathrm{C}$

Kompondibuat bentuk slab dengan menggunakan mesin hidraulic press dengan .

Pengujian Kompon bentuk slab dikondisikan al Durometer shore A

(1490 - 89 A : L is karet kaca Pengujian dilakukan sesuai kendaraan bermotor 
F hitung pada Naphthenic oil, carbon black dan interaksi keduanya menumukkan perbedaan yang sangal nyata, sehingga perhilungan dileruskan untuk menentukinl notasi masing masng I ntuk interaksi jumlah Naphlicnic oil dat carton black dinvatakan dengan notass uji Duncan's dipergunakan MI)RS, dimant Rp $\backslash$ S

$$
\frac{\sqrt{\text { RJK Kekelimum }}}{3}
$$

Rp dari tabel statistik

Dan hasil uji l)uncan's kekerasan erendah adalah kompon dengan fumlah

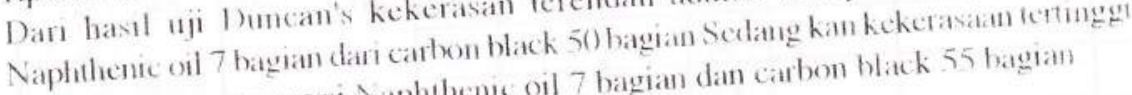
adalah yang mempunyat Vaphthenic oil 7 bagian dan carbon black 55 bagian

Pembahasan

Pada tabel ANOVA untuk kekerasan (tabel 2) faktor-faktor Naphithenc oil. carbon black dan interaksi Naphthenic oil dan carbon black berpengarub sangat nyata (tingkat kepercayaan 99\%) terhadap kekerasan. Makin tingg prosentase Naphthenic oil makin rendah kekerasannya. Sebaliknya makin tinggi carbon black kekerasann akan semakin tingi pula. Dalam penelitian kekerasan terendah dengan nilai 67 shore A kompon dengan Naphthenic oil 7 baguan dan carbon black 50 bagian masih memenuhi persyaratan SNI 1490-89A. Dan hasil uji kekerasan prototype barang jadi adalah 66 shore A pembuatan lis kaca di Industri kecil dan 70 shore A dilaksanakan di industri besar.

\section{KESIMPULAN}

Semua kompon hasil penelitian, kekerasan memenuhi persyaratan SNI 1490 $89 \mathrm{~A}$. "Lis karet kaca kendaraan bermotor" dan yang paling baik adalah kekerasan dengan nilai 67 shore A adalah hompon dengan Naphthenic oil 7 bagian dan carben black 50 bagian. Kompon lis karet yang terbaik tersebut 7 setelah dicetak menjadi lis kaca mobil diperusahaan menengah atau besar kekerasannya menjadi 70 shore A. Sedangkan jika dicetak di industri rumah tangga kekerasannya menjadi 66 shore A. Namun demikian dari hasil penelitian ini bisa disimpulkan bahwa hasil uji kekerasan hasil penelitian bisa meningkatkan mutu dari pada hasil uji kekerasan lis karet dari pasaran.

\section{DAFTAR PUSTAKA}

1. Departemen Perindustrian "Lis kaca kendaraan bermotor" SNI $1490-89 \mathrm{~A}$.

2. Mortan M, "Rubber Tecnology" Rainhold Publising, Corporation Third Printing, New York (1963).

3. Small Businne, "Publication Rubber Tecnology and Manufacture Roopnager Delhi "

4. Suntoyo Ir "Experimental Design" Iniversitas Brawijaya Malang

Vol. XIV No. 26 Th. $1998 / 1999$ 